\title{
Hubungan Komunikasi Interpersonal Guru dan Siswa Terhadap Keaktifan Belajar Siswa di SMA Kristen Pelita Kasih Makassar
}

\section{The Relationship between Interpersonal Communication of Teacher and Student on Student Learning Activeness at Pelita Kasih Christian High School Makassar}

\author{
Irene Priskila Sareong ${ }^{1)}$ \\ Tri Supartini ${ }^{2)^{*}}$ \\ 1) Sekolah Tinggi Filsafat Theologia Jaffray Makassar \\ 2) Sekolah Tinggi Filsafat Theologia Jaffray Makassar \\ *Penulis Korespondensi: trisupartini411@gmail.com
}

Received: 1205 2020/Revised: 0506 2020/ Accepted: 11062020

\begin{abstract}
Abstrak
Tujuan penelitian ini adalah untuk mengetahui hubungan komunikasi interpersonal guru dan siswa terhadap keaktifan belajar siswa pada mata pelajaran PAK di SMA Kristen Pelita Kasih Makassar. Dalam penelitian ini, penulis mengambil sampel sebanyak 32 orang siswa kelas XI di SMA Kristen Pelita Kasih Makassar. Metode penelitian yang digunakan adalah metode kuantitatif. Untuk mengumpulkan data, penulis melakukan observasi, tinjauan pustaka, wawancara dan membagikan kuisioner (angket) kepada siswa yang belajar mata pelajaran PAK di SMA Kristen Pelita Kasih Makassar. Untuk menghitung korelasi variabel $X$ terhadap $Y$, penulis menggunakan analisis korelasi Pearson Product Moment. Dari pembahasan yang ada, maka penulis menarik kesimpulan hasil analisis yang menunjukkan bahwa komunikasi interpersonal $(X)$ memengaruhi keaktifan belajar siswa $(Y)$ sebesar 67,24 \%. Hal ini menunjukkan bahwa komunikasi interpersonal guru dan siswa memiliki pengaruh yang besar terhadap keaktifan belajar siswa pada mata pelajaran PAK di SMA Kristen Pelita Kasih Makassar. Komunikasi interpersonal guru dan siswa yang baik, mampu memengaruhi keaktifan siswa dalam mengalami, transaksi belajar dan dalam proses mengatasi masalah.
\end{abstract}

Kata-kata Kunci: Belajar, Interpersonal, Keaktifan, Komunikasi.

\section{Abstract}

The purpose of this study was to know the relationship of teacher and student interpersonal communication on student learning activeness in PAK subjects at Pelita Kasih Christian High School in Makassar. In this study, the authors took a sample of 32 class XI students at Pelita Kasih Christian High School in Makassar. The research 
method used is a quantitative method. To collect data, the authors made observations, literature reviews, interviews, and distributed questionnaires (questionnaire) to students studying PAK subjects at Pelita Kasih Christian High School in Makassar. To calculate the correlation of variable $X$ to $Y$, the author uses The Pearson Product Moment correlation analysis. From the discussion, the authors draw the conclusions of the analysis that show that interpersonal communication $(X)$ influences student learning activeness $(Y)$ by $67.24 \%$. This shows that the interpersonal communication of teachers and students has a great influence on student learning activeness in PAK subjects at Pelita Kasih Christian High School in Makassar. Good interpersonal communication of teachers and students, able to influence the activeness of students in experiencing, learning transactions, and in the process of overcoming problems.

Keywords: Active, Communication, Interpersonal, Learning.

\section{PENDAHULUAN}

Sekolah merupakan lembaga pendidikan formal yang memiliki peranan penting dalam menciptakan generasi-generasi penerus bangsa yang cerdas dan berguna bagi bangsa dan negara. Tujuan pendidikan nasional dirumuskan dalam undang-undang nomor 20 tahun 2003 pasal 3: Pendidikan nasional berfungsi mengembangkan kemampuan dan membentuk watak serta peradaban bangsa yang bermartabat dalam rangka mencerdaskan kehidupan bangsa, bertujuan untuk berkembangnya potensi agar menjadi manusia yang beriman dan bertakwa kepada Tuhan yang Maha Esa, berakhlak mulia, sehat, berilmu, cakap, kreatif, mandiri, dan menjadi warga Negara yang demokratis serta bertanggung jawab (Kompri, 2015, p. 88)

Pendidikan di Indonesia haruslah memandang pada tujuan pendidikan nasional yang menjadi tujuan akhir dari segala kegiatan pendidikan. Guru adalah media utama terselenggaranya pendidikan yang baik. Peranan guru sangat penting untuk mengembangkan potensi anak sehingga terbentuklah generasi bangsa yang cerdas dan bertanggungjawab. "Guru adalah orang yang berpengalaman dalam bidang profesinya. Dengan keilmuan yang dimilikinya, dia dapat menjadikan anak didik menjadi orang cerdas" (Kompri, 2015, p. 281). Keberhasilan guru dilihat dari kemampuannya dan pencapaian tujuan akhir pengajaran yang telah dilakukan

Pola pendidikan sebelum era ini, guru berperan sebagai komunikator dan siswa hanya mendengar saja. Pada pembelajaran yang berpusat pada guru, guru jadi satusatunya sumber belajar dan peserta didik menerima pengetahuan secara pasif (Marwiyah, 2018, p. 39). Jadi, dalam kegiatan pembelajaran segala ide, pendapat dan pengetahuan hanya bersumber dari guru. Menurut Nurani Soyomukti, "demokrasi dalam kelas memandang bahwa guru bukan sebagai satu-satunya sumber, tetapi hanyalah fasilitator untuk mengembangkan potensi-potensi dan pengalaman personal murid-muridnya" (Soyomukti, 2015, p. 189). Maksudnya adalah setiap pihak 
yang terlibat dalam pembelajaran dapat berpartisipasi langsung dalam pembelajaran. Guru mata pelajaran hanya sebagai media bagi pengembangan diri peserta didik.

Guru dalam pembelajaran bertindak sebagai fasilitator yang memandu, mengarahkan dalam pembelajaran dan salah satu sumber belajar yang aktif di kelas. Guru tidak mendominasi keseluruhan kegiatan pembelajaran melainkan membangkitkan keaktifan peserta didik (Faturrohman, 2015, p. 24). Dalam kegiatan pembelajaran, guru memberi kesempatan kepada siswa mengembangkan pengetahuan yang dipelajari di kelas. Potensi-potensi yang dimiliki oleh siswa harus dikembangkan secara aktif dengan bimbingan guru di kelas. Keaktifan peserta didik yang menjadi penekanan dalam pendidikan era ini dan seharusnya terlaksana dalam pembelajaran.

Sebuah penelitian menunjukkan bahwa terdapat hubungan positif komunikasi interpersonal antara guru dan siswa dengan keaktifan belajar siswa kelas XI program keahlian teknik otomotif di SMK Muhammadiyah 4 Klaten Tengah tahun ajaran 2012/2013 (Rozaq, 2012, p. 75). Berdasarkan hasil penelitian tersebut, komunikasi interpersonal dapat memengaruhi keaktifan belajar siswa. Komunikasi interpersonal yang baik antara guru dan siswa memiliki pengaruh yang positif. Hal ini penting diperhatikan oleh guru sebagai fasilitator, komunikator dan organisator dalam kegiatan belajar mengajar.

Menurut Hardjana, "Komunikasi interpersonal adalah interaksi tatap muka antar dua atau beberapa orang, di mana pengirim dapat menyampaikan pesan secara langsung, dan penerima pesan dapat menerima dan menanggapi secara langsung pula" (Hardjana, 2007, p. 85). Sedangkan Kurniawati mengatakan bahwa komunikasi interpersonal adalah komunikasi yang jika secara langsung dilakukan menimbulkan kontak pribadi antar komunikator dan komunikan di mana tujuan dari komunikasi interpersonal adalah untuk memengaruhi orang lain mengubah sikap dan pandangan terhadap suatu hal (Alang, 2018, p. 73). Hal ini sebenarnya setiap hari terjadi dalam pembelajaran di sekolah. Karena komunikasi yang terjadi antara guru dan siswa berlangsung secara tatap muka dan memiliki tujuan yang jelas sesuai tujuan pendidikan pada umumnya.

Komunikator (sumber informasi) dan komunikan (penerima pesan) memiliki peranan penting untuk terjadinya suatu komunikasi. Guru harus mampu mengembangkan kemampuan dalam hal berkomunikasi secara efektif, empatik, dan santun dengan peserta didik (Rusman, 2017, p. 166). Kemampuan komunikasi guru menunjang keefektifan kegiatan pembelajaran. Guru dan siswa yang aktif di dalam kelas menjadikan suasana belajar yang menyenangkan dan efektif. Pendidikan di kelas tidak berlangsung dengan baik apabila hanya salah satu komponen saja yang aktif. Iswan Riyadi mengatakan bahwa dalam komunikasi, guru dan siswa memiliki peran yang sama, yaitu masing-masing sebagai pemberi dan penerima aksi. Hal tersebut baik untuk dilakukan untuk menghidupkan suasana belajar (Riyadi, 2015, p. 76). Diibaratkan aksi dan reaksi, komunikasi harus berjalan seimbang sehingga susah 
lagi dibedakan mana aksi dan mana reaksi, mana komunikan dan komunikator dalam pembelajaran.

Sama halnya dengan pembelajaran lain, mata pelajaran PAK membutuhkan teknik komunikasi yang baik antara guru dan siswa agar kegiatan belajar mengajar berjalan dengan baik. Guru PAK harus kreatif dalam segala bidang termasuk menciptakan suasana yang baik dalam kelas, relasi antar pibadi yang baik dengan siswa dan keterampilan untuk menyajikan pelajaran sehingga membangkitkan keaktifan siswa berpikir, bertanya dan konsentrasi terhadap penyampaian materi pelajaran (Nainggolan, 2010, p. 131). Komunikasi yang efektif pada pembelajaran PAK memungkinkan setiap peserta didik dapat tertarik dan aktif selama proses pembelajaran.

Pada kenyataannya dalam kegiatan belajar mengajar, tidak semua dapat berjalan sebagaimana yang diharapkan. Salah satunya adalah masalah ketidakaktifan siswa. Umumnya, yang terjadi di lapangan adalah banyak siswa yang tidak aktif baik bertanya, merespons pertanyaan guru dan dalam semua kegiatan yang dilakukan ketika pembelajaran berlangsung. Keadaan yang seperti ini berakibat pada keefektifan pembelajaran (Nurdyansyah dan Fitriyani Toyiba, n.d.). Noddings mengatakan bahwa "banyak siswa yang datang ke kelas dengan sejarah pembelajaran pasif, yang telah diarahkan agar dapat membaca jawaban yang benar untuk suatu pertanyaan daripada upaya intelektual yang diajukan untuk berpikir lebih kompleks" (Santrock, 2017, p. 12). Dapat dilihat bahwa kebiasaan belajar pasif yang dilakukan siswa di kelas berpengaruh terhadap suasana belajar maupun pemahaman siswa terhadap materi pelajaran yang diterima. Kegiatan siswa di kelas hanya mendengar penjelasan materi yang disampaikan guru tetapi tidak mau terlibat dalam kegiatan-kegiatan belajar lainnya.

Hal yang sama juga ditemui oleh penulis ketika melakukan wawancara kepada guru dan siswa di SMA Kristen Pelita Kasih Makassar. Hasil wawancara menunjukkan bahwa dalam kegiatan belajar mengajar yang dilakukan di kelas masih mengalami hambatan yaitu ketidakaktifan siswa di kelas. Walaupun tidak semua siswa pasif di kelas, tetapi didapati beberapa siswa yang tidak aktif dalam memberi pertanyaan, tanggapan maupun jawaban atas pertanyaan yang diberikan guru. Selain itu, yang menjadi penyebab siswa tidak aktif bertanya dan menjawab dalam kelas karena ada beberapa guru yang cuma menjelaskan materi pelajaran dan tidak memberi kesempatan kepada siswa untuk bertanya. Selain itu, beberapa guru masih kaku dan tegang dalam mengajar karena menganggap jika dirinya lembut kepada siswa maka siswa menjadi santai. Hal ini kelihatannya baik, namun mengakibatkan siswa tertekan dan takut untuk bertanya.

Mengacu pada hal tersebut, guru dan siswa seyogianya perlu meningkatkan komunikasi interpersonal sehingga siswa dapat aktif dalam setiap proses belajar. Sebab menurut Murtiningsih dkk, komunikasi interpersonal sangat berperan penting guna mencapai saling pengertian tentang masalah yang akan dibahas sehingga pada akhirnya sampai kepada titik terjadinya perubahan perilaku ((Murtiningsih et al., 2019, 
p. 250). Namun pada kenyataannya di lapangan, komunikasi antara guru dan siswa kurang terjalin dengan baik, sehingga keaktifan siswa di dalam kelas menjadi berkurang. Untuk itulah penulis terdorong untuk melakukan penelitian ini. Namun, pada penelitian ini penulis berfokus hanya pada komunikasi interpersonal guru dan siswa pada mata pelajaran PAK dan hubungannya terhadap peningkatan keaktifan siswa dalam mata pelajaran tersebut.

\section{TEORI}

\section{Definisi Komunikasi Interpersonal}

Komunikasi digambarkan sebagai proses yang bukan saja berfokus pada apa yang akan dikatakan, tetapi juga teknik penyampaian dan hasil atau efek dari komunikasi itu. Komunikasi adalah hubungan antarpribadi dengan menggunakan sistem simbol verbal (kata-kata) dan nonverbal melalui tatap muka langsung maupun media lain (tulisan, oral, visual) (Suprapto, 2009, p. 6). Jadi, komunikasi adalah proses penyampaian informasi dengan menggunakan bahasa verbal dan nonverbal kepada orang lain dengan sebuah tujuan tertentu.

Jika komunikasi adalah sebuah proses penyampaian informasi kepada orang lain guna mencapai tujuan tertentu, komunikasi interpersonal adalah "sarana" yang digunakan dalam proses penyampaian informasi tersebut seperti mengelola, mengendalikan, merencanakan, dan memimpin (Bambacas \& Patrickson, 2008, p. 52). Itu sebabnya Hulbar dan Capon menyatakan bahwa dalam komunikasi interpersonal, respons yang ditimbulkan umumnya langsung dan tersedia bagi peserta lain, yang perilakunya dapat mereka modifikasi sendiri. (Hulbert \& Capon, 1972, p. 28).

Selanjutnya DeVito mendefinisikan "Keterampilan komunikasi interpersonal sebagai kemampuan seseorang dalam melakukan komunikasi secara efektif dengan orang lain" (Deborah, 2015, p. 4). Nofrion mengatakan bahwa komunikasi interpersonal sebagai proses pertukaran informasi dari pengirim dan penerima dan secara langsung diketahui respons baliknya (Nofrion, 2018, p. 152). Nurani Soyomukti mengatakan bahwa "komunikasi interpersonal pada hakikatnya adalah interaksi antara seorang individu dan individu lainnya tempat lambang-lambang pesan digunakan terutama menggunakan bahasa" (Soyomukti, 2016, p. 141). Terlihat bahwa komunikasi antarpribadi melibatkan dua atau beberapa orang dengan tujuan adanya pertukaran informasi.

Jadi, komunikasi interpersonal adalah komunikasi antar individu yang merupakan interaksi di mana terjadi pertukaran informasi. Dalam interaksi ini pengirim dapat berfungsi sebagai pendengar dan sebaliknya. Kegiatan pembelajaran menggunakan komunikasi interpersonal menjadikan komunikasi berjalan efektif dikarenakan komunikasi interpersonal berlangsung dua arah, guru - siswa dan siswa - guru. Respons pendengar dan pengirim pesan dapat secara langsung dilihat dalam komunikasi ini. 


\section{Komunikasi Interpersonal antara Guru dan Murid dalam Alkitab}

Komunikasi interpersonal antara guru dan murid juga dapat ditemukan dalam Alkitab. Salah satu contoh yang dapat dijadikan teladan ialah komunikasi interpersonal yang terjadi antara Tuhan Yesus dan murid-murid-Nya. Dalam penelitian yang diadakan oleh Asmat Purba, setidaknya ada sembilan bentuk kreatifitas Tuhan Yesus dalam membangun hubungan dengan murid-murid-Nya yang patut dijadikan teladan oleh para pengajar PAK (Purba, 2015, p. 70-71).

1. Tuhan Yesus membuka dirinya (Yoh. 1:6-8).

2. Tuhan Yesus mampu menghadapi semua masalah dan semua orang, baik yang menerima-Nya maupun yang menolaknya, baik orang berdosa maupun orang benar.

3. Tuhan Yesus memiliki daya tarik (Yoh. 2:12; 3:31).

4. Isi pengajaran Tuhan Yesus bertolak dari diri-Nya sebagai utusan Allah.

5. Tuhan Yesus membentuk komunitas bersama murid-murid-Nya.

6. Tuhan Yesus adalah seorang gembala, pemimpin, pembagi makanan, mendisiplin dan melindungi, guru bahkan pelatih bagi murid-murid-Nya.

7. Tuhan Yesus menyebut diri-Nya sebagai hamba Allah, Anak Allah, sebagai guru dan gembala.

8. Tuhan Yesus adalah penyembuh dan pemulih jiwa yang letih lesu dan berbeban berat (Mat. 11:28).

9. Tuhan Yesus murid-murid-Nya sebagai sahabat (Yoh. 15:15).

Berdasarkan kesembilan hal di atas, penulis mengambil kesimpulan bahwa Tuhan Yesus adalah guru Agung yang sepatutnya dijadikan teladan oleh setiap pengajar PAK sebab la tidak hanya mementingkan diri-Nya sendiri melainkan la juga merangkul murid-murid-Nya untuk dapat berkarya bersama-sama dengan-Nya melakukan misi Kerajaan Allah. Untuk itu, hasil dari pengajaran-Nya membuktikan bahwa tak sedikit dari murid-murid-Nya yang pada akhirnya mencapai kesuksesan dalam pelayanan-Nya. Kebanyakan murid-murid-Nya yang menjalani hidup mereka dengan menjadi saksi Kristus dalam hal pemberitaan Injil sampai ke berbagai tempat.

\section{Definisi Keaktifan Belajar}

Keaktifan belajar merupakan hasil yang diperoleh siswa selama belajar di sekolah, yang merupakan perpaduan dari tiga ranah kognitif, afektif dan psikomotorik (Sinar, 2018, p. 15) Menurut Ruswandi Hermawan, dkk, "keaktifan belajar adalah kemampuan siswa untuk mengkonstruksikan pengetahuannya sendiri" (Jawadha, 2016, p. 27). Jadi, dapat disimpulkan bahwa keaktifan belajar adalah kemampuan peserta didik untuk menyusun dan membangun sendiri pengetahuan yang didapat melalui proses belajar. 


\section{Bentuk-bentuk Keaktifan Belajar}

Keaktifan belajar berkaitan dengan kegiatan-kegiatan aktif yang dilakukan oleh siswa baik di dalam kelas maupun diluar kelas. Usman mengelompokkan aktivitas dalam pembelajaran dengan 5 kegiatan yaitu visual, lisan, mendengarkan, gerak, menulis (Wahyuni, 2014, p. 100). Sejalan dengan Usman, Paul D. Dierich juga membagi kegiatan belajar, namun agak lebih luas lagi dengan membagi kegiatan belajar dalam 8 kelompok, yaitu: (Hamalik, 2016, p. 172).

1. Kegiatan-kegiatan visual (membaca, melihat gambar-gambar, mengamati eksperimen, demonstrasi, pameran, mengamati orang lain bekerja atau bermain).

2. Kegiatan-kegiatan lisan (mengemukakan suatu fakta atau prinsip, menghubungkan suatu kejadian, mengajukan pertanyaan, memberi saran, mengemukakan pendapat, wawancara, diskusi, dan interupsi).

3. Kegiatan-kegiatan mendengarkan (mendengarkan penyajian bahan, percakapan atau diskusi kelompok).

4. Kegiatan-kegiatan menulis (menulis cerita, laporan, rangkuman dll).

5. Kegiatan-kegiatan menggambar (menggambar, membuat grafik, dll)

6. Kegiatan-kegiatan metrik (melakukan percobaan, memilih alat-alat, menari, dII).

7. Kegiatan-kegiatan mental (merenungkan, mengingat, menganalisis)

8. Kegiatan-kegiatan emosional (minat, membedakan berani, tenang, dan lain-lain.

9. Kegiatan ini terdapat dalam semua kegiatan lain).

Kegiatan-kegiatan yang dilakukan menunjukkan bahwa siswa aktif baik secara visual, lisan, menulis, mendengarkan. Akan tetapi seringkali hanya beberapa jenis kegiatan yang dilakukan oleh siswa. Dari beberapa jenis kegiatan belajar yang dikemukakan oleh Dierich dan Usman, dapat disimpulkan bahwa siswa dikatakan aktif di kelas jika melakukan kegiatan-kegiatan belajar.

Keaktifan siswa dalam peristiwa pembelajaran meliputi berbagai kegiatan dari segi fisik yang mudah diamati maupun psikis yang sulit diamati. Namun, yang menjadi penghambat keaktifan belajar adalah guru yang mendominasi pembelajaran sehingga siswa hanya menunggu sajian dari guru tanpa menemukan sendiri pembelajaran yang diperlukan (Dimyati dan Mudjiono, 2013, p. 117). Dari segi fisik kegiatan seperti visual, menulis, dan lain sebagainya. Namun dari segi psikis ketika siswa melakukan kegiatan mental dengan menganalisis pelajaran yang diterima di kelas. Paham yang salah ketika guru menganggap hanya dirinya yang dapat menjadi sumber satu-satunya dalam pembelajaran sehingga menjadi halangan bagi siswa belajar secara aktif di kelas.

Menurut Sinar, keaktifan proses belajar mengajar dapat diukur melalui pengamatan terhadap kegiatan belajar siswa di kelas. Ada tiga hal indikator keaktifan belajar yaitu proses mengalami, transaksi atau peristiwa belajar aktif dan proses mengatasi masalah (Sinar, 2018, p. 18). Nugroho Wibowo mengatakan bahwa keaktifan siswa dapat dilihat dari berbagai hal seperti memperhatikan (visual activities), mendengarkan, berdiskusi, kesiapan siswa, bertanya, keberanian siswa, 
mendengarkan, memecahkan soal (mental activities) (Wibowo, 2016, p. 130). Pada dasarnya kedua pendapat ini memiliki kesamaan dalam hal mengukur keaktifan belajar yang dimulai dengan mendengar, aktif dalam kegiatan belajar mengajar, kemudian mampu mengatasi atau memecahkan persoalan.

Berdasarkan indikator keaktifan belajar, dalam kegiatan belajar keaktifan siswa dapat dipantau perkembangannya. Proses belajar yang merupakan kegiatan aktif 1guru dan siswa untuk saling berinteraksi. Dan melalui interaksi tersebut, guru dapat melihat apakah pembelajaran yang diterapkan oleh guru kepada murid membuahkan hasil atau kurang berdampak.

\section{Pengaruh Komunikasi Interpersonal Terhadap Keaktifan Belajar Siswa}

Seperti yang telah dijelaskan sebelumnya mengenai komunikasi dalam pendidikan. Salah satu jenis komunikasi yang paling ampuh mempersuasif peserta didik adalah komunikasi interpersonal. Komunikasi ini baik diterapkan dalam pendidikan karena komunikasi yang baik antara guru dan siswa harusnya membawa kedekatan secara interpersonal, adanya keterbukaan dari masing-masing pihak, kesetaraan dalam hal berbicara dan mendengarkan selama proses pembelajaran. Teknik komunikasi yang dilakukan oleh guru dan hubungan yang baik dengan siswa dapat mempersuasi siswa sehingga meningkatkan keaktifan dalam belajar di kelas.

Keaktifan belajar siswa di kelas terlihat ketika siswa aktif melakukan berbagai kegiatan yang melibatkan mental dan fisik. Kegiatan aktif siswa adalah kegiatan di mana siswa dapat belajar melalui mengalami sendiri, transaksi dalam kegiatan belajar dan yang terakhir adalah bagaimana siswa dapat memecahkan masalah berdasarkan apa yang telah dipelajari.

Khusus dalam Pendidikan Agama Kristen, komunikasi interpersonal yang baik dengan guru PAK dapat menimbulkan kedekatan interpersonal yang baik antara guru dan siswa. Hal ini menjadi salah satu jalan bagi guru dengan efektif menyampaikan pembelajaran yang tidak hanya menambah pengetahuan melainkan menjadi sebuah kegiatan aktif ketika siswa mengalami sendiri, siswa melakukan tanya jawab untuk lebih memahami dan berpikir serta memberi solusi dalam pemecahan masalah. Keaktifan adalah usaha guru dalam mengusahakan peserta didik aktif baik jasmani dan rohani (Rifai, 2016, p. 140). Oleh karena itu, komunikasi interpersonal dibutuhkan oleh guru untuk meningkatkan keaktifan belajar siswa di mata pelajaran PAK.

\section{METODE}

Dalam penelitian ini, penulis menggunakan metode kuantitatif. Adapun populasi dalam penelitian ini adalah seluruh siswa SMA Kristen Pelita Kasih Makassar. Jumlah keseluruhan siswa di SMA Pelita Kasih Makassar adalah 117 orang. Namun dalam penelitian ini, penulis hanya meneliti siswa kelas XI yang berjumlah 32 orang. Penulis menentukan sampel menggunakan Non-probability sampling dengan teknik Sampling Purposive. Penulis dalam penelitian ini, mengambil sampel kelas XI SMA 
Kristen Pelita Kasih Makassar. Alasan memilih kelas XI karena pada kelas XI siswa telah dapat menyesuaikan diri dengan lingkungan sekolah dan guru-guru. Inilah yang menyebabkan penulis tertarik untuk meneliti kelas XI.

Selain itu, alasan penulis tidak memilih kelas $X$, karena siswa kelas $X$ umumnya masih belum terlalu mengenal guru dan banyak berkomunikasi sebab masih dalam tahap adaptasi dari jenjang SMP ke SMA. Kelas XII tidak dipilih oleh penulis sebagai sampel karena pada saat penelitian, siswa kelas XII telah mengikuti ujian akhir sehingga tidak aktif lagi ke sekolah.

\section{Teknik Pengumpulan Data}

Adapun teknik pengumpulan data yang digunakan penulis dalam penelitian ini adalah observasi dengan memberi tahu sumber data tentang penelitian ini dan mengamati sehingga penulis mendapatkan gambaran tentang komunikasi interpersonal dan keaktifan siswa dalam pembelajaran khususnya mata pelajaran PAK. Dalam hal ini, penulis mengumpulkan data dan teori dari buku-buku, jurnal yang berhubungan dengan penelitian. Dari sumber tersebut diperoleh informasi yang mendukung teori penelitian ini. Penulis mengumpulkan data dengan melakukan wawancara dengan beberapa guru dan murid SMA Kristen Pelita Kasih Makassar. Dalam pengumpulan data penelitian ini, penulis mengumpulkan data dengan membagikan angket kepada 32 siswa.

\section{Teknik Analisis Data}

Setelah mengumpulkan data yang diperlukan dalam penelitian ini, penulis menganalisis data yang diperoleh dari penelitian kuantitatif dengan menggunakan rating skala. "Rating scale lebih fleksibel, tidak hanya untuk mengukur sikap, tetapi juga dapat digunakan untuk mengukur persepsi responden terhadap fenomena lingkungan, seperti skala untuk mengukur status sosial, ekonomi, pengetahuan, kemampuan dan lain-lain" (Wijaya, 2016, p. 80). Di bawah ini adalah rumus perhitungan skor Rating scale dan contoh analisis angket menggunakan Rating Scale (Sugiyono, 2017, p. 99).

Rating scale $=\frac{\text { Jumlah skor hasil penghitungan data }}{\text { Jumlah skor kriterium }}$

Skor kriterium = Jumlah skor tertinggi $\mathrm{x}$ Jumlah butir soal $\mathrm{x}$ jumlah responden.

\section{HASIL DAN PEMBAHASAN}

Setelah penulis melakukan penelitian, data yang diperoleh melalui kuisioner (angket) yang telah diisi responden, selanjutnya diolah dan dianalisis dengan menggunakan teknik Rating scale, kemudian disajikan dalam bentuk tabel. Angket 
dibuat dengan pernyataan yang menyediakan 4 alternatif jawaban: skor 4 untuk sangat baik, 3 untuk baik, 2 untuk cukup baik dan 1 untuk tidak baik.

\section{Subjek Penelitian}

Dalam penelitian ini penulis membagikan angket kepada 32 orang siswa kelas XI MIPA dan kembali 32 angket (100\%). Sedangkan unutk wawancara, sebanyak 4 orang (3 siswa, 1 guru PAK). Berikut akan digambarkan dalam bentuk tabel.

Tabel 1. Profil siswa Kelas XI

\begin{tabular}{|c|c|c|}
\hline Jenis Kelamin & Jumlah (orang) & Persentase (\%) \\
\hline Laki-laki & 13 & 40,63 \\
\hline Perempuan & 19 & 59,37 \\
\hline Total & 32 & 100 \\
\hline
\end{tabular}

\section{Analisis Data}

\section{Komunikasi Interpersonal Guru dan Siswa}

Jumlah skor kriterium $=$ jumlah skor tertinggi $\mathrm{x}$ jumlah soal $\mathrm{x}$ jumlah responden

$$
=4 \times 18 \times 32=2304
$$

Hasil yang diperoleh melalui angket yaitu 1843 .

Rating skala $=1843 / 2304=0,80=80 \%$

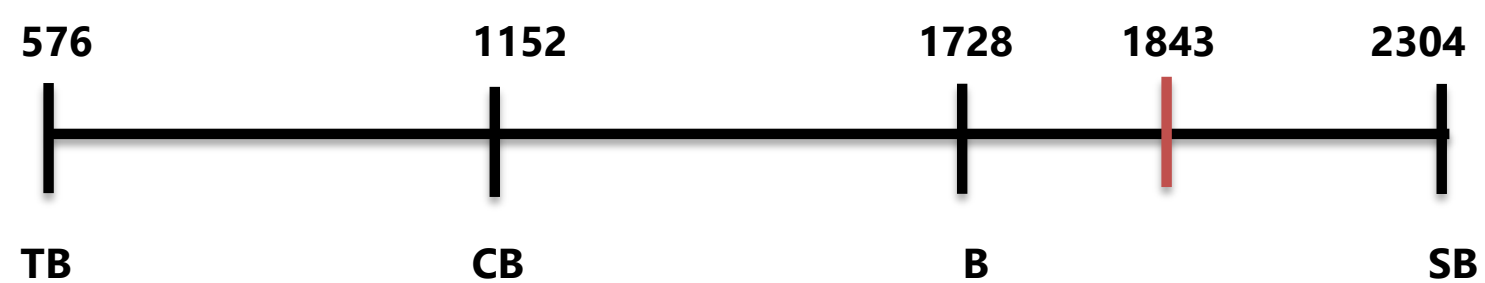

Berdasarkan data yang diperoleh, komunikasi interpersonal guru dan siswa pada pembelajaran PAK di SMA Kristen Pelita Kasih Makassar berada pada interval baik dan sangat baik. Dengan skor yang diperoleh melalui angket yaitu 1843, lebih besar dari skor maksimal untuk interval baik dan lebih kecil dari skor 2304 untuk interval sangat baik. Komunikasi interpersonal guru dan siswa dalam penerapannya sudah mencapai 80 \% yang berarti sudah terjalin dengan baik. Terlihat bahwa guru PAK sudah melakukan interaksi dengan baik.

\section{Keaktifan Belajar Siswa}

Jumlah skor kriterium $=$ jumlah skor tertinggi $\times$ jumlah soal $\times$ jumlah responden

$$
=4 \times 12 \times 32=1536
$$

Hasil yang diperoleh melalui angket yaitu 1173 . 
Rating skala $=1173 / 1536=0,76=76 \%$

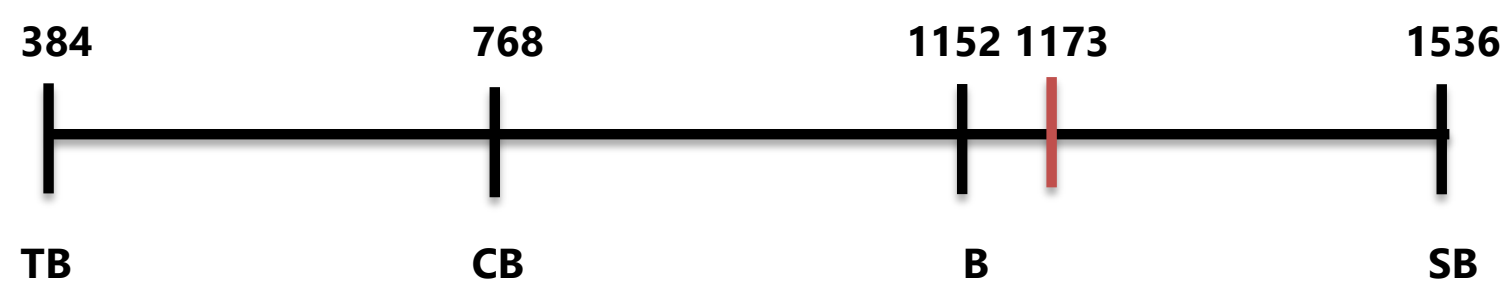

Berdasarkan data yang diperoleh, keaktifan belajar siswa pada pembelajaran PAK di SMA Kristen Pelita Kasih Makassar berada pada interval baik dan sangat baik. Dengan skor yang diperoleh melalui angket yaitu 1173, lebih besar dari skor 1152 untuk interval baik dan lebih kecil dari skor 1536 untuk interval sangat baik. Keaktifan belajar siswa dalam mata pelajaran PAK di SMA Kristen Pelita Kasih Makassar sudah mencapai 76 \% yang berarti keaktifan belajar siswa sudah baik.

\section{Korelasi Komunikasi Interpersonal Dan Keaktifan Belajar}

Untuk mengetahui bahwa nilai koefisien korelasi indikator $\mathrm{X}_{1-6}$ terhadap indikator $\mathrm{Y}_{1-3}$ berarti atau signifikan untuk menggeneralisasi populasi maka perlu mengadakan uji signifikansi dengan membandingkan $r$ hitung dan $r$ tabel. Nilai $r$ tabel didapatkan dengan melihat tabel pearson product moment berdasarkan jumlah data yang dianalisis (n), yang di dalam perhitungan ini 32 data dengan derajat kebebasan 30 ( $n-2)$. Di mana $r_{\text {tabel }}$ pada taraf signifikansi 0,05 adalah 0,349 dan pada taraf signifikansi 0,01 adalah 0,449.

\section{Korelasi Variabel $X$ terhadap $Y$}

Tabel 2. Korelasi Variabel $\mathrm{X}$ terhadap Variabel $\mathrm{Y}$

\begin{tabular}{|c|c|c|c|c|c|}
\hline $\mathbf{X}$ & $\mathbf{Y}$ & $\mathbf{X}^{\mathbf{2}}$ & $\mathbf{Y}^{\mathbf{2}}$ & $\mathbf{X Y}$ & rXy \\
\hline 1843 & 1173 & 1008263 & 44065 & 68791 & 0,82 \\
\hline
\end{tabular}

Koefisien korelasi 0,82 > 0,339 dan 0,82 > 0,449. Jadi, koefisien korelasi 0,82 sangat signifikan atau sangat berarti. Dapat disimpulkan bahwa terdapat pengaruh positif antara komunikasi interpersonal guru dan siswa $(X)$ terhadap keaktifan belajar siswa (Y) pada pelajaran PAK di SMA Kristen Pelita Kasih Makassar. Artinya, jika komunikasi interpersonal guru dan siswa baik, maka keaktifan belajar siswa juga baik.

Selanjutnya, untuk mengetahui besarnya variabel $X$ terhadap variabel $Y$ digunakan rumus koefisien penentu (KP) yaitu :

$K P=r^{2} \times 100 \%$

Dimana :

KP : koefisien penentu

$r=$ nilai korelasi Pearson Product Moment 
$K P=0,82^{2} \times 100 \%=67,24 \%$

Jadi, pengaruh komunikasi interpersonal guru dan siswa terhadap keaktifan belajar siswa sebesar 67,24\%.

Adapun kesimpulan analisis dari hasil penelitian ini adalah sebagai berikut. Indikator komunikasi interpersonal yang diteliti yaitu: timbal balik, feedback langsung, komunikator dan komunikan dapat bergantian fungsi, dapat secara spontanitas, tidak berstruktur, terjadi antara dua orang. Sedangkan indikator keaktifan belajar yang diteliti yaitu: mengalami, transaksi, dan proses mengatasi masalah. Hasil penelitian yang dilakukan oleh penulis dapat disimpulkan sebagai berikut:

Pertama, pengaruh indikator komunikasi interpersonal terjadi antara dua orang atau lebih $\left(X_{6}\right)$ terhadap proses mengalami $\left(Y_{1}\right)$ sebesar $84 \%(0,56)$. Hal ini berarti bahwa komunikasi yang terjadi antara dua orang atau lebih dalam pembelajaran mampu menciptakan interaksi edukatif yang mendukung sehingga siswa dengan bimbingan guru dapat belajar aktif yang diawali dengan bertanya, menjawab pertanyaan teman dan mempraktikkan materi yang sedang dipelajari.

Kedua, indikator feedback langsung $\left(X_{2}\right)$ terhadap transaksi $\left(Y_{2}\right)$ sebesar 60,6\%. Hal ini menunjukkan bahwa indikator $X_{2}$ mampu memengaruhi $Y_{2}$ cukup baik. Dibandingkan dengan indikator lain, $X_{2}$ memiliki pengaruh yang lebih besar. Jadi, feedback langsung dalam pembelajaran mampu memengaruhi transaksi belajar atau kegiatan belajar yang di dalamnya siswa saling membantu, memahamkan dan terbentuk kerjasama yang baik.

Ketiga, indikator dapat secara spontanitas $\left(X_{4}\right)$ terhadap proses mengatasi masalah $\left(\mathrm{Y}_{3}\right)$ sebesar 56,1 \%. Hal ini berarti bahwa komunikasi yang berlangsung secara spontan yang terjadi dalam pembelajaran mampu memengaruhi proses mengatasi masalah yang didalamnya ada praktek dan diakhiri dengan melaporkan hasil diskusi dan solusi terhadap topik kasus yang diberikan oleh guru.

\section{KESIMPULAN}

Berdasarkan uraian dan analisis yang telah dikemukakan di atas, maka hasil penelitian ini dapat disimpulkan sebagai berikut:

Pertama, komunikasi interpersonal guru dan siswa dengan 6 indikator (timbal balik, feedback langsung, komunikator dan komunikan dapat bergantian fungsi, dapat secara spontan, tidak berstruktur dan terjadi antara dua orang atau lebih) pada mata pelajaran PAK di SMA Kristen Pelita Kasih Makassar berada pada kategori baik dan telah $80 \%$ diterapkan dalam kegiatan belajar mengajar.

Kedua, keaktifan belajar siswa dengan 3 indikator (proses mengalami, transaksi, proses mengatasi masalah) pada mata pelajaran PAK di SMA Kristen Pelita Kasih Makassar masuk dalam kategori baik dan telah 76\% tercapai. 
Ketiga, hasil analisis menunjukkan bahwa komunikasi interpersonal guru dan siswa mampu memengaruhi keaktifan belajar siswa pada mata pelajaran PAK di SMA Kristen Pelita Kasih Makassar sebesar 67,24 \%. Hal ini berarti bahwa komunikasi interpersonal memiliki pengaruh yang cukup besar terhadap keaktifan belajar siswa di kelas.

\section{KEPUSTAKAAN}

Alang, S. (2018). Komunikasi Interpersonal Guru Dalam Meningkatkan Keaktifan Belajar Siswa Kelas X Jurusan Teknik Sepeda Motor Di Smk Negeri 1 Parigi. Kinesik, 1(1), 1-11. http://garuda.ristekbrin.go.id/documents/detail/1321791.

Bambacas, M., \& Patrickson, M. (2008). Interpersonal Communication Skills That Enhance Organisational Commitment. Journal of Communication Management, 12(1), 51-72. https://doi.org/10.1108/13632540810854235.

Deborah, G. O. (2015). Keterampilan Komunikasi Interpersonal Guru Dalam

Menyampaikan Materi Pelajaran Kepada Murid Tunarungu Di SLB-B Karya Mulia

Surabaya. Jurnal E-Komunikasi, 3(2), 1-12. http://publication.petra.ac.id/index.

php/ilmu-komunikasi/article/view/4915.

Dimyati dan Mudjiono. (2013). Buku Belajar dan Pembelajaran. Jakarta: Rineka Cipta. Faturrohman, M. (2015). Paradigma Pembelajaran Kurikulum 2013: Strategi Alternatif

Pembelajaran di Era Global. Yogyakarta: Kalimedia.

Hamalik, O. (2016). Proses Belajar Mengajar. Jakarta: Bumi Aksara.

Hardjana, A. M. (2007). Komunikasi Interpersonal Dan Intrapersonal. Yogyakarta: Kanisius.

Hulbert, J., \& Capon, N. (1972). Interpersonal Communication in Marketing: An

Overview. Journal of Marketing Research, 9(1), 27-34.

https://doi.org/10.1177/002224377200900107.

Jawadha, A. (2016). Implementasi Penggunaan Modul Untuk Meningkatkan Keaktifan dan Prestasi Belajar Pada Pembelajaran Pemeliharaan Mesin Kendaraan Ringan

Kelas XI Otomotif SMK Ma'arif Wates. Skripsi, UNY, 2016.

https://eprints.uny.ac.id/33752/.

Kompri. (2015). Manajemen Pendidikan 1. Bandung: Alfabeta.

Marwiyah, St., Alauddin, dan Muhammad Khaerul Ummah BK. (n.d.) Perencanaan

Pembelajaran Kontemporer Berbasis Penerapan Kurikulum 2013. Yogyakarta: Deepublish.

Murtiningsih, Kristiawan, M., \& Lian, B. (2019). The Correlation Between Supervision

Of Headmaster And Interpersonal Communication With Work Ethos Of The

Teacher. European Journal of Education Studies, 6(1), 246-256.

https://oapub.org/edu/index.php/ejes/article/view/2398/5036.

Nainggolan, John M. (2010). Guru Agama Kristen Sebagai Panggilan dan Profesi.

Bandung: Bina Media Informasi.

Nofrion. (2018). Komunikasi Pendidikan. Jakarta: Kencana. 
Nurdyansyah dan Fitriyani Toyiba. (n.d.). Pengaruh Strategi Pembelajaran Aktif Terhadap Hasil Belajar Pada Madrasah Ibtidaiyah.

http://eprints.umsida.ac.id/1610/1/jurnal\%20Nds\%20dan\%20toy\%20Fiks.pd.

Purba, A. (2015). Kreatifitas Yesus Dalam Membangun Hubungan Interpersonal

Dengan Murid-Muridnya Dan Implementasinya Bagi Dosen Pendidikan Agama

Kristen. Jurnal TEDC, 9(1), 69-75. http://ejournal.poltektedc.ac.id/index.php/ tedc/article/view/244.

Rifai. (2016). Penelitian Tindakan Kelas PAK: Classroom Action Research in Christian Class. Sukoharjo: BornWin's Publishing.

Riyadi, I. (2015). Model Pembelajaran Berbasis Metakognisi untuk Peningkatan Kompetensi Siswa pada Mata Pelajaran IPS. Yogyakarta: Deepublish.

Rozaq, Fadly. (2012). Hubungan Komunikasi Interpersonal antara Guru dan Siswa dengan Keaktifan Belajar Siswa Kelas XI Program Keahlian Teknik Otomotif di SMK Muhammadiyah 4 Klaten Tengah Tahun Ajaran 2012/2013. Skripsi ST, Universitas Negeri Yogyakarta. https://eprints.uny.ac.id/20288/1/FADLI\%20ROZ AQ\%2008504241036.pdf.

Rusman. (2017). Belajar dan Pembelajaran: Berorientasi Standar Proses Pendidikan. Jakarta: Prenada Media.

Santrock, J. W. (2017). Psikologi Pendidikan. Jakarta: Salemba Humanika.

Sinar. (2018). Metode Active Learning - Upaya Peningkatan Keaktifan dan Hasil Belajar Siswa. Yogyakarta: Deepublish.

Soyomukti, N. (2015). Teori-Teori Pendidikan dari Tradisional, (Neo) Liberal, MarxisSosialis, Hingga Postmodern. Yogyakarta: Ar-Ruzz Media.

Soyomukti, N. (2016). Pengantar Ilmu Komunikasi. Yogyakarta: Ar-Ruzz Media.

Sugiyono. (2017). Metode Penelitian Kuantitatitf, Kualitatif dan $R \& D$ Bandung: Alfabeta.

Suprapto, T. (2009). Pengantar Teori \& Manajemen Komunikasi. Yogyakarta: MedPress.

Wahyuni, S. (2014). Peningkatan Keaktifan Dan Hasil Belajar IPS Melalui Model Group Investigation (GI) Pada Siswa Kelas VI SDN Bandung, Wonosegoro. Scholaria: Jurnal Pendidikan Dan Kebudayaan, 4(3), 97-106. https://doi.org/10.24246/j.scholaria.2014.v4.i3.p97-106.

Wibowo, N. (2016). Upaya Peningkatan Keaktifan Siswa Melalui Pembelajaran Berdasarkan Gaya Belajar Di SMK Negeri 1 Saptosari. Elinvo (Electronics, Informatics, and Vocational Education), 1(2), 128-139. https://doi.org/10.21831/elinvo.v1i2.10621.

Wijaya, H. (2016). Analisis Data Kualitatif Ilmu Pendidikan Teologi. Sekolah Tinggi Teologia Jaffray Makassar. 